\title{
POTENSI AZOLLA SEBAGAI SUBSTITUSI PUPUK KANDANG PADA BUDIDAYA PADI ORGANIK
}

\author{
Jauhari Syamsiyah" ${ }^{1)}$, Bambang Hendro Sunarminto ${ }^{2)}$ dan Mujiyo $^{1)}$ \\ ${ }^{1)}$ Program Studi Ilmu Tanah, Fakultas Pertanian, Universitas Sebelas Maret, Surakarta \\ 2) Jurusan Ilmu Tanah Fakultas Pertanian, Universitas Gadjah Mada, Yogyakarta \\ Email: ninukts@yahoo.com
}

\begin{abstract}
One of problems faced by farmers in the rice cultivation with organic system is organic fertilizer limited, especially for farmers who do not have livestock. Azolla is one of materials that can be used as organic fertilizer. The aim of the research was to determine whether Azolla (Azolla mycrophylla L.) is able to meet the nutrient needs of some rice varieties on organic rice cultivation. The experiment used factorial complete randomized block design with three factors and three replications. Azolla was spread at days after transplanting and at 25 days after transplanting, $75 \%$ of Azolla was incorporated into soil and the rest was left up until rice were harvested. Meanwhile, cow manure was distributed after tillage. The treatment consisted of rice varieties (Miral, Mentik Wangi and Red and White), Azolla ( 0 and 2 tons / ha) and manure ( 0 and 10 tons / ha). The result showed that Azolla did not significantly increase growth and yield of rice, despite it could increase the $N$ uptake 5,4\% and $P$ uptake $P 17,3 \%$, weight of dry straw, dry grain and 1,000 seeds by 5,86\%, 12.7\%, 7.37\% than without Azolla respectively. Azolla 2 tons/ha with manure 10 tons/ha were able to increase $N$ uptake by $7.6 \%$, the uptake $P$ by $13.7 \%$ and the of productive tiller number by $9.88 \%$. From the standpoint of crop yields with organic system, a single use of Azolla has not been able to replace manure.
\end{abstract}

Keywords: azolla, nutrient uptake, organic paddy field, rice production

\section{PENDAHULUAN}

Peningkatan kesadaran masyarakat akan pentingnya makanan yang sehat perlu diimbangi dengan cara budidaya yang sehat pula. Sistem pertanian organik merupakan pilihan yang tepat, karena dalam sistem itu, semua komponen produksi yang bersifat anorganik ditinggalkan. Sistem pertanian organik dalam budidaya padi belum sudah di programkan pemerintah telah lama memprogramkan dengan "Go Organik 2010" Namun perkembangan nya agak lambat. Ada beberapa kendala, salah satunya adalah penyediaan pupuk organik. Perlu dicari sumber bahan orgaanik alternatif yang dapat digunakan untuk menggantikan pupuk kandang, bagi petani yang tidak mempunyai ternak.

Azolla merupakan tanaman air yang dapat dipilih untuk memenuhi kebutuhan pupuk organik. Sifatnya yang mudah berkembang biak bersama dengan pertumbuhan padi merupakan salah satu keunggulan dari Azolla, disamping kemampuannya dalam menambat Nitrogen yang efisien melalui asosiasi simbiosis dengan Blue-Green Algae, Anabaena azollae.
Subedi dan Shrestha (2015) menjelaskan bahwa Azolla tidak hanya meningkatkan produktivitas padi, tetapi juga meningkatkan kesuburan tanah jangka panjang. Meskipun demikian begaimana potensinya untuk memenuhi kebutuhan pupuk organik pada sawah organik masih perlu dikaji. Penelitian ini bertujuan untuk mengkaji penggunaan Azolla pada sawah organik terhadap serapan hara dan hasil beberapa varietas padi.

\section{METODE PENELITIAN}

Penelitian ini dilaksanakan pada tanah Inceptisols dengan $\mathrm{pH} 5,2, \mathrm{C}$ organik 2,42\%, $\mathrm{N}$ total $1,22 \%$, $\mathrm{P}$ tersedia $4,33 \mathrm{ppm}, \mathrm{K}$ tersedia $0,15 \mathrm{cmol}(+)$ dan KTK 24,02 $\mathrm{cmol}(+)$ di Desa Sukorejo, Sambirejo, Sragen, Sedangkan Azolla mempunyai kadar N 2,1 $4 \%$, P 0,96\% , K 2,64\% dan C organik 37,9\%. Penelitian ini menggunakan 3 varietas padi yaitu Mira-1, Mentik Wangi dan Merah Putih, 2 taraf Azolla 0 dan 2 ton/ha dan pupuk kandang (0 dan 10 ton/ha). Azolla ditebar setelah tanam padi berumur 5 hari setelah tanam ( HST) dan pada umur $25 \mathrm{HST}, 75 \%$ Azolla dan sisanya dibiarkan sampai tanaman padi dipanen. Sedangkan Pupuk kandang sapi diberikan secara merata setelah pengolahan tanah. 
Percobaan ini menggunakan Rancangan Acak Kelompok Lengkap Faktorial (Completely Randomized Block Design factorial). Data dianalisis dengan uji $\mathrm{F}(95 \%)$ dan untuk membandingkan antar rerata perlakuan menggunakan uji DMR ( $95 \%$.) Berbagai parameter yang diukur dalam penelitian ini meliputi kadar serapan $\mathrm{N}$ dengan metode Walkey and Black, serapan $\mathrm{P}$ dengan metode Pengabuan basah $\mathrm{HNO}_{3}$ dan $\mathrm{HClO}_{4}$ (Balittanah 2005).

\section{HASIL DAN PEMBAHASAN}

\section{Pengaruh Perlakuan Terhadap Serapan Hara Tanaman}

\section{Serapan Nitrogen (N)}

Hasil penelitian menunjukkan tidak ada perbedaan serapan $\mathrm{N}$ beberapa varietas padi dengan pemberian Azolla dan pupuk kandang, Pupuk kandang sapi berpengaruh sangat nyata terhadap serapan N. Pupuk kandang yang diberikan diduga telah mengalami proses perombakan secara sempurna melalui proses mineralisasi (aminisasi, amonifikasi dan nitrifikasi) dalam bentuk terlarut, terikat lempung atau terikat pada kompleks humus. Sehingga semakin tinggi dosis yang diberikan maka akan diikuti peningkatan kandungan $\mathrm{N}$ dalam tanah.

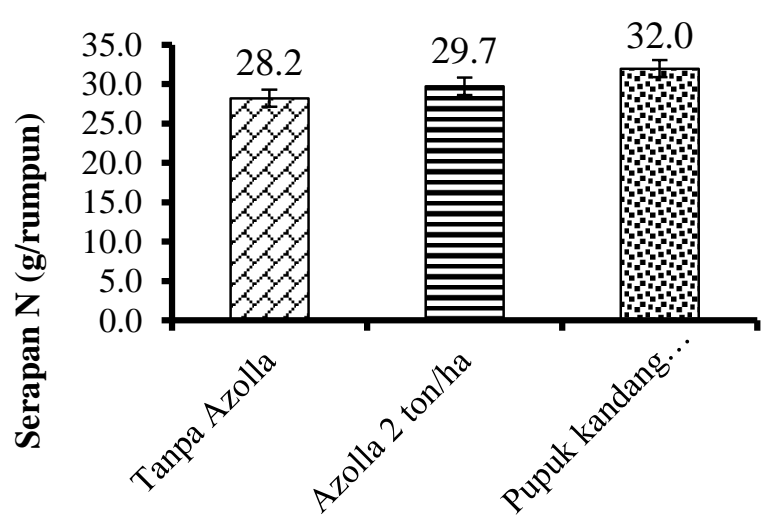

Gambar 1. Pengaruh Azolla (A) terhadap Serapan N.

Gambar 1 menunjukkan bahwa pemberian Azolla 2 ton/ha mampu meningkatkan serapan hara N 5,4\% dibandingkan tanpa Azolla, sedangkan dengan pemberian Azolla 2 ton/ha + pupuk kandang 10 ton/ha mampu meningkatkan $7,6 \%$ serapan $\mathrm{N}$ dibandingkan penambahan Azolla saja, meskipun hasil tersebut tidak berbeda nyata. Hasil yang sama diperoleh Rivaie et al. (2013) yaitu pemberian Azolla dengan dosis 2,5-10 ton/ha tidak memberikan pengaruh yang nyata terhadap serapan N. Hal ini mungkin disebabkan karena faktor lingkungan seperti iklim. Hasil penelitian Macale et al. (2002) mengungkapkan bahwa pola serapan $\mathrm{N}$ dengan pemberian Azolla mengalami peningkatan yang signifikan selama musim kemarau. Penyerapan nitrogen di seluruh tanaman meningkat sebanyak $40,8 \%$ pada musim kemarau.

2. Efisiensi Serapan Nitrogen (N)

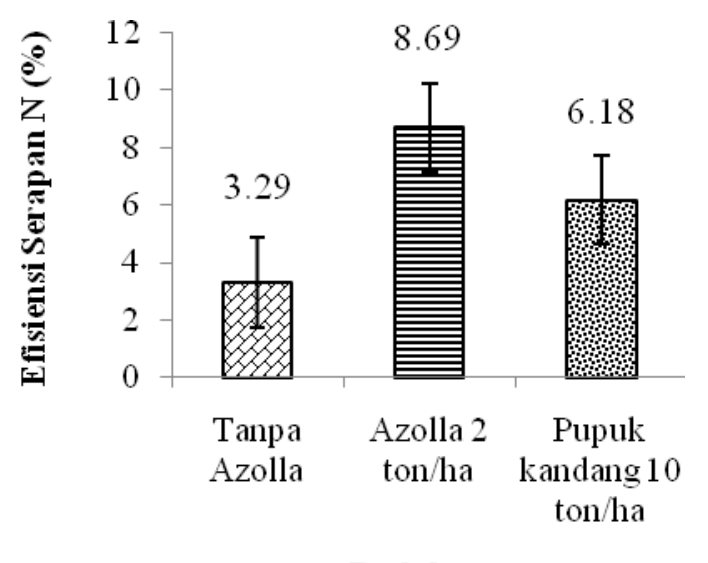
Gambar 2. Pengaruh Azolla dan Pupuk Kandang terhadap Efisiensi Serapan N (\%).

Hasil analisis sidik ragam terhadap efisiensi serapan $\mathrm{N}$, menunjukkan bahwa interaksi antara varietas, pupuk kandang sapi dan Azolla berpengaruh nyata terhadap efesiensi serapan $\mathrm{N}$. Berdasarkan uji korelasi dapat diketahui bahwa serapan $\mathrm{N}$ berkorelasi positif dengan efisiensi serapan $\mathrm{N} \quad\left(\mathrm{r}=0,496^{* *}\right)$. Efisiensi yang tinggi berarti pupuk yang diserap tanaman lebih banyak dibandingkan yang hilang. Hasil penelitian menunjukkan efisiensi serapan $\mathrm{N}$ tertinggi terdapat padapemberian Azolla + Pupuk Kandang pada varietas Merah Putih $(15,71 \%)$ dan berbeda nyata dengan perlakuan lainnya. Takaran Azolla 2 ton/ha mampu meningkatkan $164 \%$ efisisensi serapan $\mathrm{N}$ dibandingkan tanpa Azolla, dan peningkatan 40,6\% jika dibandingkan dengan pupuk kandang 10 ton/ha, meskipun tidak berbeda nyata. 
3. Serapan Fosfor (P)

Kadar optimal fosfor dalam tanaman pada saat pertumbuhan vegetatif adalah 0,3-0,5\% dari berat kering tanaman (Rosmarkam dan Yuwono 2002). Hasil analisis sidik ragam terhadap serapan $\mathrm{P}$, menunjukkan bahwa pupuk kandang sapi, Azolla, dan interaksi ketiga perlakuan berpengaruh tidak nyata terhadap serapan $\mathrm{P}$, sedangkan varietas berpengaruh nyata terhadap serapan $\mathrm{P}$.

Pemberian pupuk kandang 10 ton/ha+Azolla 2 ton/ha) pada Varietas Mira -1 menghasilkan serapan $P$ cenderung lebih dibandingkan dengan perlakuan yang lain meskipun tidak signifikan yaitu sebesar 0,028 mg/tanaman. Pemberian Azolla mampu meningkatkan serapan $\mathrm{P}$ 17,3\% dibandingkan tanpa Azolla.

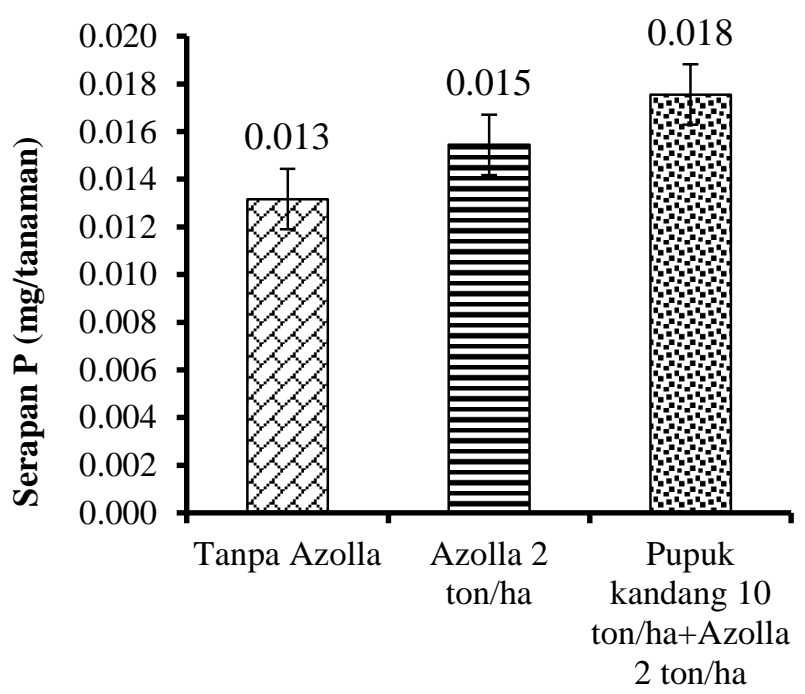

Gambar 3. Pengaruh Azolla dan Pupuk Kandang terhadap Serapan P (mg/ tanaman).

Sedangkan kombinasi antara Azolla 2 ton/ha+pupuk kandang 10 ton/ha memberikan peningkatan 13,7\% dibandingkan dengan pemberian Azolla.

Menurut Hakim et al. (1986), pemanfaatan azolla sebagai bahan organik yang dapat menjadikan $\mathrm{P}$ menjadi tersedia sehingga dapat di manfaatkan azolla untuk tumbuh. Dengan adanya Azolla dan Pupuk Kandang, sebagai bahan organik yang dapat terdekomposisi selain sebagai sumber $\mathrm{P}$ organik juga dpat meningkatkan asam asam organik yang dapat melepas $\mathrm{P}$ yang terikat oleh kation $\mathrm{Al}, \mathrm{Fe}$ dan $\mathrm{Ca}$ sehingga senyawa $\mathrm{P}$ dapat tersedia bagi tanaman.

\section{Pengaruh Perlakuan Terhadap Hasil Tanaman Padi (Oryza sativa L.)}

1. Jumlah Anakan Produktif

Berdasarkan analisis ragam diketahui bahwa varietas tanaman padi, perlakuan pupuk kandang dan Azolla maupun interaksi ketiganya memberikan pengaruh yang tidak nyata terhadap jumlah anakan produktif. Pemberian Azolla tidak memberikan pengaruh nyata diduga hara $\mathrm{N}$ tidak diserap belum memenuhi kebutuhan padi karena belum semua $\mathrm{N}$ yang berasal dari Azolla terurai menjadi $\mathrm{N}$ yang siap diserap tanaman. Serapan N diukur pada saat tanaman memasuki masa vegetatif maksium. Pada periode tersebut masih ada Azolla yang tumbuh di area sawah. Hal lain yang mempengaruhi adalah kandungan $P$ tesedia pada tanah awal yang rendah, karena unsur hara $\mathrm{P}$ sangat berperan dalam menguatkan sistem perakaran tanaman sehingga dapat dihasilkan anakan produktif yang banyak.

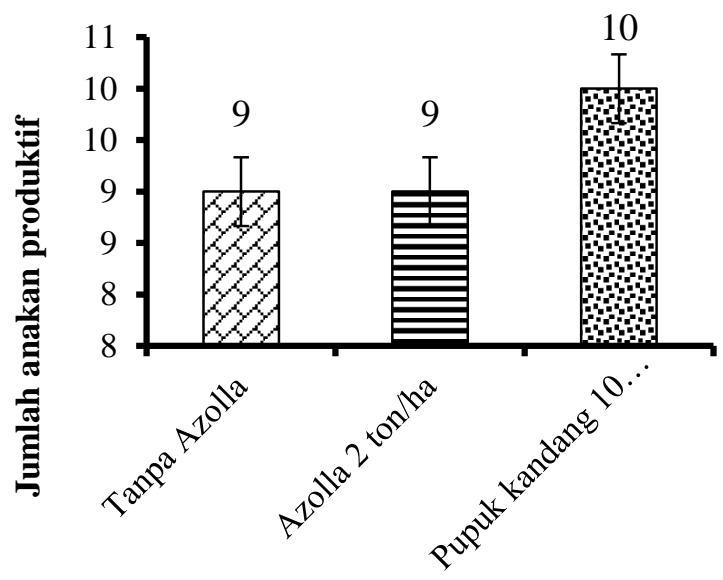

Gambar 4. Pengaruh Azolla dan Pupuk Kandang terhadap Jumlah Anakan Produktif.

Jumlah anakan produktif tanaman yang diberi 0 dan 2 ton/ ha Azolla adalah sama yaitu masing-masing 9 batang per rumpun. Hal ini menunjukkan efektivitas Azolla dengan takaran 2 ton/ha belum mampu memberikan kebutuhan hara yang optimal bagi pertumbuhan padi. Peningkatan jumlah anakan produktif sebesar $9,88 \%$ terjadi apabila pemberian Azolla disertai dengan pembetian pupuk kandang 10 ton/ha.

2. Berat Brangkasan kering

Berdasarkan analisis ragam terhadap berat brangkasan kering dapat diketahui 
bahwa dari semua perlakuan yaitu varietas, pupuk kandang dan Azolla serta interaksi ketiganya berpengaruh tidak nyata terhadap berat brangkasan kering. Kondisi ini menunjukkan bahwa pada pertanian padi organik penggunaan Azolla belum mampu menjadi sumber pupuk utama. Hasil penelitian menjunkkan ada korelasi nyata $(\mathrm{r}=0,402 *)$ antara berat brangkasan kering dengan serapan $\mathrm{P}$ tanaman.

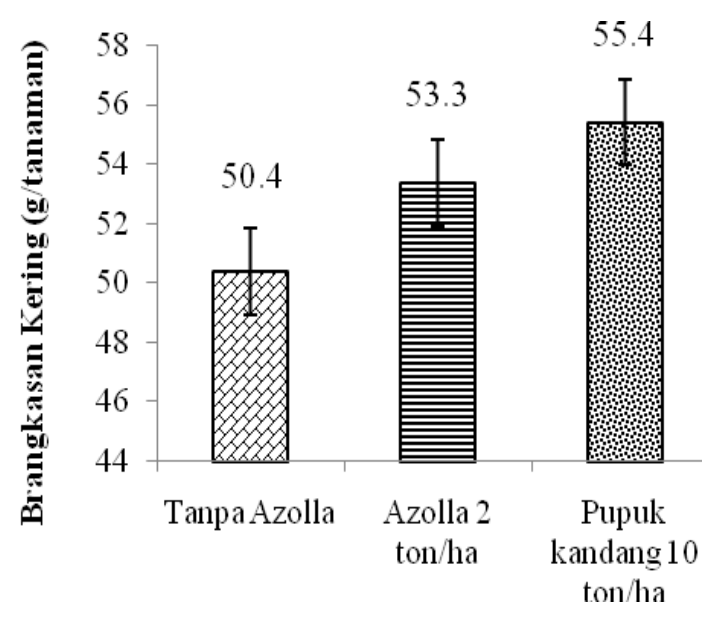

Gambar 5. Pengaruh Azolla dan Pupuk Kandang terhadap Berat Brangkasan Kering (g/ tanaman).

Pemberian Azolla 2 ton/ha memberikan berat brangkasan kering 3,7 $\%$ lebih rendah dibandingkan dengan pemberian pupuk kandang 10 ton/ha, meskipun meningkat 5,86\% dibandingkan tanpa Azolla (Gambar 5). Hasil tersebut menunjukkan penggunaan Azolla sebanyak 2 ton/ha masih belum mencukupi kebutuhan hara yang diperlukan tanaman. Meskipun Azolla mampu meningkatkan sifat fisika dan kimia tanah antara lain hara $\mathrm{N}, \mathrm{Mg}, \mathrm{Ca}, \mathrm{Na}$ dan bahan organik tanah. Awodun (2008). Ketersediaan unsur hara bagi tanaman yang cukup merupakan salah satu faktor penting untuk menunjang pertumbuhan dan perkembangan tanaman (Harjadi, 2007).

\section{Berat Gabah Kering Panen (GKP)}

Hasil analisis sidik ragam menunjukkan bahwa tidak ada pengaruh interaksi ayang nyata antara Azolla, Pupuk kandang dan Varietas padi maupun perlakuan Azolla saja, sedangkan varietas padi (V) dan perlakuan pupuk kandang (K) masing-masing berpengaruh sangat nyata terhadap gabah kering panen.

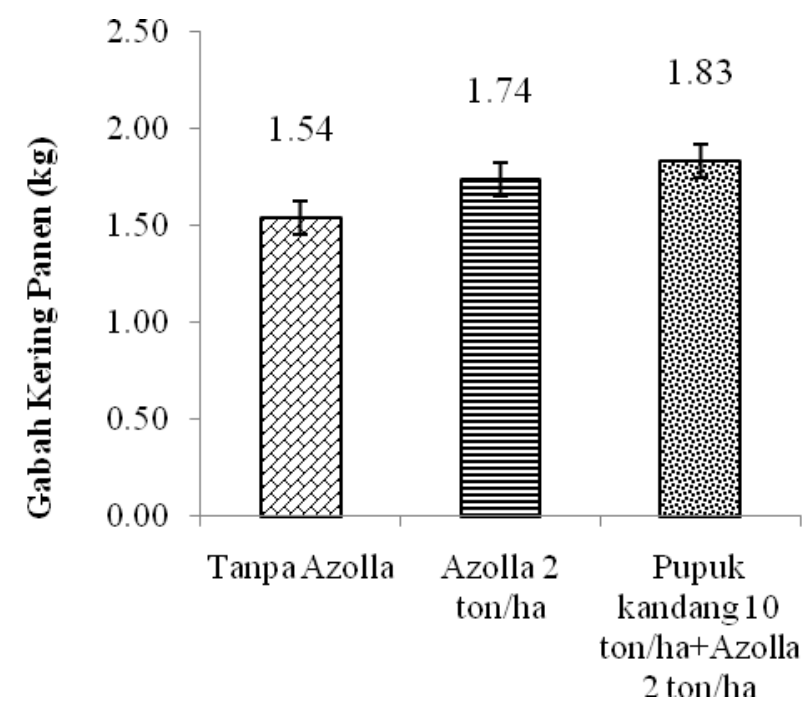

Gambar 6. Pengaruh Azolla dan Pupuk Kandang terhadap Gabah Kering Panen (kg).

Berdasarkan hasil tersebut terlihat bahwa pemberian Azolla 2 ton/ha juga belum mampu memenuhi kebutuhan hara tanaman padi dengan sistem organik, meskipun ada peningkatan hasil gabah sebesar 12,7\% dibandingkan tanpa Azolla. Azolla tidak memberikan pengaruh nyata terhadap GKP diduga karena takaran yang digunakan sedikit. Berdasarkan hasil penelitian Bharati et al. (2000), pemberian Azolla menghasilkan peningkatan GKP yang signifikan dibandingkan pemberian urea. Berdasarkan hasil penelitian Rivaie (2013), berat gabah kering panen dipengaruhi oleh pemberian Azolla dengan perolehan GKP tertinggi pada kisaran takaran 5 hingga 7,5 ton/ha, dan untuk Azolla segar disarankan untuk hasil yang maksimal yaitu pada takaran 4,6 ton/ha atau 8 ton/ha.

Hasil penelitian juga menunjukkan bahwa varietas Mira-1 memiliki produksi gabah kering panen yang tertinggi dibandingkan dua varietas lainnya. Sedangkan pemberian Azolla 2 ton/ha disertai pupuk kandang 10 ton/ha dapat meningkatkan gabah kering panen 5,63\% dibandingkan dengan Azolla saja. Berdasarkan uji korelasi, ada korelasi positif antara GKP dengan serapan $\mathrm{N}$ $\left(\mathrm{r}=0,323^{\text {ns }}\right)$ dan $\mathrm{P}\left(\mathrm{r}=0,559^{* *}\right)$. 
Pupuk kandang memberikan pengaruh sangat nyata terhadap GKP. Berat gabah kering panen yang dihasilkan dengan pemberian pupuk kandang 10 ton/ ha adalah $1,87 \mathrm{~kg} / 9 \mathrm{~m}^{2}$. Hartatik dan Widowati (2011) mengatakan bahwa kombinasi SP36 dengan pukan kerbau 5 ton/ ha meningkatkan pertumbuhan tanaman dan bobot kering gabah. Pemberian jerami dan pukan kerbau meningkatkan serapan hara K. Berdasarkan hal tersebut, pemupukan P yang dikombinasikan dengan pemberian jerami dan pukan disarankan pada lahan sawah yang berkadar bahan organik rendah dan kahat K (Suriadikarta et al. 2003).

4. Berat $1000 \mathrm{Biji}$

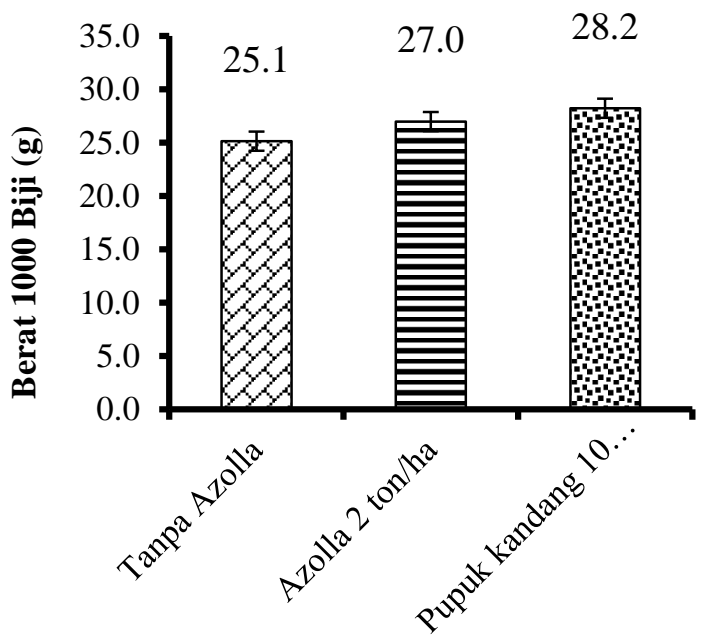

Gambar 7. Pengaruh Azolla dan Pupuk Kandang terhadap Berat 1.000 biji

Hasil analisis ragam, tidak ada interaksi nyata antar Azolla, pupuk kandang dan varietas padi terhadap perlakuan. berat 1000 biji. Pemberian Azolla secara tunggal juga tidak memberikan pengaruh yang nyata meskipun ada peningkatan berat 1000 biji sebesar 7,37\% dibandingkan tanpa Azolla, namun lebih rendah dibandingkan dengan Azolla 2 ton/ha + pupuk kandang 10 ton/ha yang mampu meningkatkan berat 1000 biji sebesar 12,3\% dibandingkan tanpa perlakukan (kontrol). Hasil penelitian juga menunjukkan korelasi positif antara serapan hara $\mathrm{N}\left(\mathrm{r}=0,142^{\mathrm{ns}}\right)$ dan $\mathrm{P}(\mathrm{r}=$ $\left.0,415^{*}\right)$ dengan berat 1000 biji. Varietas Mira-1 menghasilkan berat 1000 biji yang hampir sama dengan varietas Merah Putih tetapi, berbeda sangat nyata dengan Mentik Wangi.

\section{KESIMPULAN DAN SARAN}

Pemberian Azolla 2 ton/ha belum mampu memberikan peningkatan terhadap pertumbuhan dan hasil padi pada sawah organik. Pemberian Azolla 2 ton/ha meningkatkan serapan $\mathrm{N} 5,4 \%$; serapan $\mathrm{P}$ 17,3\%; berat brangkasan kering 5,86\%; gabah kering panen (GKP) 12,7\%; dan 7,37\% berat 1.000 biji dibandingkan tanpa Azolla. Pemberian Azolla 2 ton/ha disertai pupuk kandang 10 ton/ha mampu meningkatkan serapan $\mathrm{N} \mathrm{7,6 \%}$; serapan $\mathrm{P} 13,7 \%$; jumlah anakan produktif 9,88\%; GKP 5,63\%; dan berat 1.000 biji $4,56 \%$ dibandingkan pemberian Azolla. Serapan hara $\mathrm{N}$ dan $\mathrm{P}$ berkorelasi positif dengan jumlah anakan produktif, brangkasan kering, GKP, dan berat 1.000 biji

Dosis Azolla untuk penelitian selanjutnya perlu ditingkatkan agar pengaruhnya dapat lebih nyata dan dapat mensubtitusi penggunaan pupuk kandang.

\section{UCAPAN TERIMAKASIH}

Penulis mengucapkan terimakasih kepada Direktorat Jenderal Pendidikan Tinggi (Dirjen Dikti) yang telah memfasilitasi pendanaan untuk pelaksanaan penelitian.

\section{DAFTAR PUSTAKA}

Awodun MA 2008. Effect of azolla (Azolla species) on physiochemical properties of soil. World Journal of Agricultural Sciences 4(2): 157-160

Balai Penelitian Tanah. 2006. Pusat penelitian dan pengembangan tanah dan agroklimat. Badan Penelitian dan Pengembangan Pertanian Departemen Pertanian. Bogor.

Basroh, M, 2000. Pengaruh pemupukan kotoran ayam dan pospor terhadap pertumbuhan dan produksi jagung. Departemen Ilmu Tanah Fakultas Pertanian IPB.

Bharati K, SR Mohanty, DP Singh,VR Rao, TK Adhya 2000. Influence of incorporation or dual cropping of Azolla on methane emission from a flooded alluvial soil planted to rice in eastern India. Agriculture, Ecosystems and Environment 79: 73-83 
Erickson AJ, RS Ramsewak AJ Smucker, MG Nair 2000. Nitrification inhibitor from the roots of Leucaena leucocephala. Jurnal of Agricultural and Food Chemistry 48(12). 6174-6177.

France C, Lindström K, Elmerich C 2009. Nitrogen-fixing bacteria associated with leguminous and non-leguminous plants. Plant and Soil Vol. 321(1): 35-59.

Hakim N, Nyakpa, MY Lubis, AM. Nugroho, SG Saul, MR Dina, MA Hong, GB dan Bailey, H.H 1986. Dasar-dasar Ilmu Tanah. Universitas Lampung. Bandar Lampung.

Harjadi, S. S. 2007. Pengantar Agronomi. Gramedia. Jakarta.

Hartatik W dan LR Widowati 2011. Pupuk kandang. Diakses dari balittanah.litbang.deptan.go.id/dokumenta si/buku/pupuk/pupuk4.pdf.(16 Agustus 2015)

Macale MAR de, PLG Vlek, GO San V 2002. The role of azolla cover in improving the nitrogen use efficiency of lowland rice. International Symposium Sustaining Food Security and Managing Natural Resources in Southeast Asia - Challenges for the 21st Century - January 8-11, 2002 at Chiang Mai, Thailand. $10 \mathrm{pp}$

Patti PS, Kaya E, Silahooy Ch 2013. Analisis Status Nitrogen Tanah dalam Kaitannya Dengan Serapan N oleh Tanaman Padi
Sawah di Desa Waimital, Kecamatan Kairatu, Kabupaten Seram Bagian Barat. Agrologia Vol. 2 (1):. 51-58.

Rivaie AA, Soni I, Maryati 2013. Changes in Soil N, P, K, rice growth and yield following the application of Azolla pinnata. Journal of Biology, Agriculture and Healthcare Vol. 3(2):112-118

Rosmarkam A dan Yuwono WN 2002. Ilmu Kesuburan Tanah. Kanisius. Yogyakarta.

Subedi P dan Shrestha J 2015. Improving soil fertility through Azolla application in low land rice: A review. Azarian Journal of Agriculture Vol 2(2): 35-39.

Suriadikarta DA, W Hartatik, G Syamsidi 2003. Penerapan pengelolaan hara terpadu pada lahan sawah irigasi. Dalam Prosiding Seminar Nasional PERHIMPI. Biotrop, 9-10 September 2003.

Suyono AD, Citraresmini A 2010. Komposisi kandungan fosfor pada tanaman padi sawah (Oryza Sativa L.) berasal dari pupuk p dan bahan organik. BionaturaJurnal Ilmu-ilmu Hayati dan Fisik Vol. 12 (3): 126-135.

Syam M 2008. Padi organik dan tuntutan peningkatan produksi beras. Iptek Tanaman Pangan Vol. 3 (1):1-8.

Wijayaratri $\mathrm{Y}$ 2001. Transformasi N (nitrifikasi) dalam lahan kering: dampak negatif dan pencegahannya. Agros. Vol 2. No. 2: 79-88. 